\title{
Textile packaging - the connection between science and health
}

\author{
DOI: $10.35530 / I T .071 .02 .1636$
}

\section{ABSTRACT - REZUMAT}

\section{Textile packaging - the connection between science and health}

According to the Report presented in the ONU Program for Development there are eight dimensions of international security (collective security) and national security: economic-social security, food security, environmental security, community security, personal security, political security and individual security, to which demographic security and military security could be added. Although there have been concerns about the nutrition status of the population since ancient times, it was only in the middle of the last century that the scientific and institutional bases of contemporary food and nutrition policies were laid.

Food and nutrition policies are represented by a series of objectives, priorities, norms and decisions adopted by the invested factors and institutions with the competences necessary to ensure to the entire population the economic and social conditions for a good state of individual and public health.

Packaging has become one of the most important functions of a product, of a commodity on the market. The packaging is part of the Food Contact Materials (FCMs) group, which should not affect the health of consumers or alter the quality of the products.

The breadth and complexity of the socio-economic context in the food contact sector requires finding additional ways to adapt.

In this context, the textile sector, respectively the field of technical textiles, through the potential of functionalities, can make a special contribution to achieving a level of coherence between the field of functionalized materials intended for food packaging - environment - consumer health - free movement of products - efficient functioning of the internal market.

Keywords: textile packaging, legislation, functions, requirements, principles

\section{Ambalaje textile - legatura dintre ştiinţă şi sănătate}

În conformitate cu Raportul prezentat în cadrul Programului ONU pentru Dezvoltare există 8 dimensiuni ale securităţii internaţionale (securităţii colective) şi securităţii naţionale: securitatea economico-socială, securitatea alimentară, securitatea mediului, securitatea comunităţii, securitatea personală, securitatea politică şi securitatea individuală, la care s-ar mai putea adăuga securitatea demografică şi securitatea militară. Cu toate că au existat preocupări pentru starea de nutriţie a populaţiei încă din cele mai vechi timpuri, abia spre mijlocul secolului trecut s-au pus bazele ştiinţifice şi instituţionale ale politicilor alimentare şi nutriţionale contemporane.

Politicile alimentare şi nutriţionale sunt reprezentate de o serie de obiective, priorităţi, norme şi decizii adoptate de factorii şi instituţiile învestite cu competenţele necesare pentru a asigura întregii populaţii condiţiile economico-sociale pentru o stare bună a sănătăţii individuale şi publice.

Ambalarea a devenit una dintre cele mai importante funcţii ale unui produs, a mărfurilor pe piaţă. Ambalajele fac parte din grupa Food Contact Materials (FCMs), care trebuie să nu afecteze sănătatea consumatorilor sau să modifice calitatea produselor.

Amploarea şi complexitatea contextului socio-economic din sectorul materialelor destinate contactului cu alimentele impune găsirea unor modalităţi suplimentare pentru a se adapta.

În acest context sectorul textil, respectiv domeniul textilelor tehnice, prin potenţialul funcţionalităţilor, poate avea o contribuţie deosebită la atingerea unui nivel de coerență între domeniul materialelor funcționalizate destinate ambalării alimentelor - mediu - sănătatea consumatorilor - libera circulaţie a produselor - eficientă funcţionare a pieţei interne.

Cuvinte cheie: ambalaje textile, legislație, funcţii, cerinţe, principil

\section{INTRODUCTION}

Food and drink are some of the greatest traditions and pleasures of our society. Today we have access to an impressive variety and quality of food and drinks. The food sector is an indelible part of the social, economic and cultural edifice of Europe. But, like most progresses, this comes with challenges. The European food and drink industry want to play its role as an active partner in addressing these challenges to ensure that Europe continues to have the highest quality and safest food in the world, taking care of the environment [1].

Food quality and safety have become consumers rights, with direct effects on quality of life, and issues focused on product quality and safety are the focus of the bodies set up to protect consumers interests. 
At the European level:

- Food is a fresh or processed product, with nutritional value, used as nutrition.

- Food security aims to ensure the self-sufficiency, respectively the sufficiency of food products for some target entities (areas, countries, groups of countries), with the help of food aid tools, donations, projects, programs etc.

Food security has different meanings in the literature [2]:

- Aims to ensure access for everyone to a healthy food.

- Aims to ensure food availability.

- Ensures and respects the right of every person to feed and the desire to have a healthy diet.

- It is a basic component of the social, economic stability and, explicitly, of the national security of a state (either with or without agricultural potential).

Food safety refers in particular to the safety of foodstuffs, with an emphasis on reducing, eliminating and avoiding the risks that food could pose to human and animal health.

Food safety - a component of food security - is a parameter that concerns the consumer and in its assurance all the component parts involved in the production, processing, transport and distribution of food are involved.

According to Codex Alimentarius,

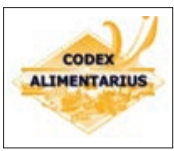

(Food

Book - a collection of internationally recognized standards, codes of good practice, food guides and recommendations, food production and food safety) food safety is "the guarantee that food will not harm consumers when they are prepared and/or consumed in accordance with the specifications regarding the use method" (table 1) [3].

For a food product - unprocessed, partially processed, totally processed or newly created - to be safe, it must meet three conditions, namely [4-6] (table 2).

\begin{tabular}{l}
$\qquad$ COMMISSION OF CODEX ALIMENTARIUS - PURPOSE \\
\hline Consumer health protection, ensuring honest practices in food trade \\
Promote the coordination of works, ensuring honest practices regarding food trade \\
Determining priorities and initiating guides for the preparation of draft standards through, and with the help of appro- \\
priate organizations \\
Finalizing the elaborated standards and publishing them in Codex Alimentarius, improving the standards after the \\
appropriate review in the light of progress.
\end{tabular}

\begin{tabular}{|c|c|}
\hline \multicolumn{2}{|r|}{ CONDITIONS THAT ENSURES FOOD SAFETY } \\
\hline Conditions & Requirements \\
\hline $\begin{array}{l}\text { Hygienic quality } \\
\text { (sanitation, safety) }\end{array}$ & $\begin{array}{l}\text { Food safety is determined by: } \\
\text { - quality of raw materials and auxiliaries; } \\
\text { - modes of transport and storage of raw materials; } \\
\text { - the hygienic-sanitary conditions and the technological processes for their processing, of } \\
\text { the storage conditions of the finished products; } \\
\text { - hygienic-sanitary conditions for transport and marketing of food products. } \\
\text { Safety/hygiene quality is an integral part of global quality and is influenced by: } \\
\text { - toxic substances that are naturally found in raw materials or finished products (alkaloids, } \\
\text { biogenic amines etc.); } \\
\text { - antinutrient substances from agri-food raw materials: hemagglutinins or lectins, trypsin } \\
\text { inhibitors, antivitamins, antimineralizers, blockers of various enzymes etc.; } \\
\text { - additives - those additives that are used in food production without compliance with the } \\
\text { legislation in effect with reference to the destination, doses etc.; } \\
\text { - chemical contaminants such as heavy metals, pesticides, mycotoxins. }\end{array}$ \\
\hline $\begin{array}{c}\text { To have nutritional and } \\
\text { energetic value }\end{array}$ & $\begin{array}{l}\text { - The intrinsic nutritional value is expressed by the quality and quantity of the main nutri- } \\
\text { ents: proteins, lipids and carbohydrates that are energy providers. Contents of minerals, } \\
\text { vitamins and other biologically active substances are also important. } \\
\text { Nutrients in food are those exogenous compounds (which come from outside the body), } \\
\text { which, after prior digestion and absorption, participate in metabolism, a process indispens- } \\
\text { able to life, while also ensuring cellular nutrition. }\end{array}$ \\
\hline $\begin{array}{l}\text { Food nutrients must be } \\
\text { available to the body }\end{array}$ & $\begin{array}{l}\text { - High bioavailable nutritional value. Food bioavailability refers to the extent to which nutri- } \\
\text { ents, biominerals, vitamins and biologically active substances are used by the human body. } \\
\text { Bioavailability is influenced by a number of factors, respectively: the physiological state of } \\
\text { the organism, the nature of the product, the presence of antinutritional substances, the way } \\
\text { of processing the raw material, the synergistic, antagonistic or associative interactions } \\
\text { between nutrients and biominerals or nutrients and vitamins. }\end{array}$ \\
\hline
\end{tabular}




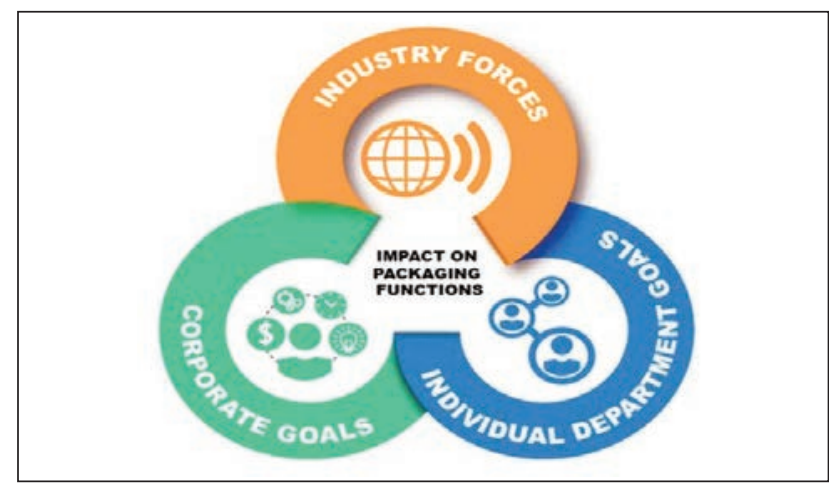

Fig. 1. The strategy of packaging [7]

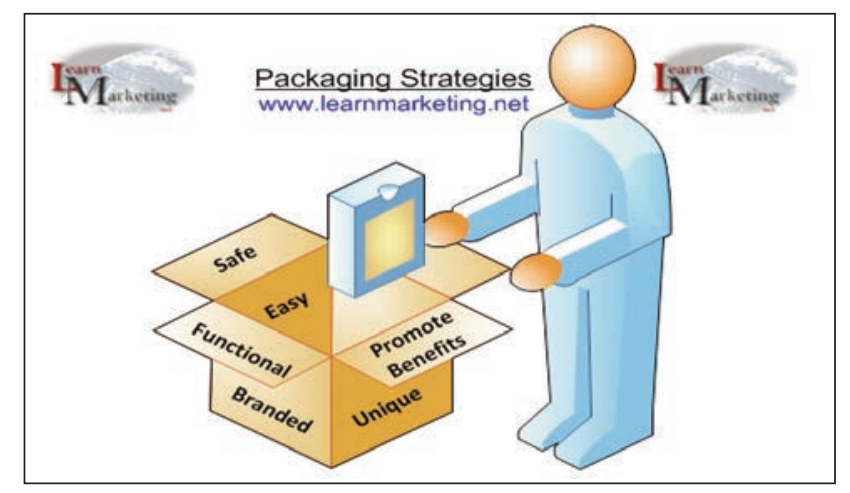

Fig. 2. The six functions of the packaging process [8]

The "packaging" strategy in the field is an important side for the sustainability of the producers and influences both the corporate objectives, the individual objectives of the departments, as well as the general objectives of the industry to which the respective producer belongs (figure 1).

The packaging offers a lot of information about the product itself from the technical point of view, of the image, but also about the content of the product. The packaging must fulfil six functions, namely: unique, functional, safe, easy to remove, to promote the benefits of the products and to strengthen the brand (figure 2).

The packaging is part of the Food Contact Materials (FCMs) group, which should not affect the health of consumers or alter the quality of the products.

According to the specialized literature, the materials intended for contact with food have been presented in different marketing contexts:

- as marketing instruments mix-Seven $\mathrm{P}=$ Product, Prices, Promotion, Place, Packaging, Positioning, People;

- as a link element between production, price, distribution, promotion;

- as a way of expressing the functions and values of packaging in relation to the needs and requirements of consumers;

- as an element in the context of the strategy of a product;

- as a component part of a promotion strategy;

- as a source of emotions and experience for consumers;

- as an education and information platform for consumers.

Packaging and goods form a system that generates interdependent relationships that are established between the component elements of the system.

The packaging will physically protect the product and will also act as a barrier against microbiological or chemical contamination, the packaging itself should not be a source of contamination of the packaged product.

Materials intended for contact with food must meet a variety of requirements. Most importantly, they must be non-toxic and chemical resistant to legal requirements. In addition, it must have a low permeability to gases, vapours and liquids, resistance to perforation,

some transparency, low costs, good processability and biodegradation capacity.

The current trends noted in the conception of packaging and packaging methods are:

- reducing the consumption of raw materials, materials and energy;

- increasing the preservation life of the products;

- enhancing the performance of the packaging by combining the manufacturing materials;

- facilitating the reintegration of packaging in the post-consumption stage into the environment.

\section{TEXTILE PACKAGING - REQUIREMENTS AND PERFORMANCE}

The materials intended for contact with food can be considered as standalone products or as part of a different product, their importance is reflected both in the performance of the functions and in the decisionmaking process regarding the purchase by consumers.

The magnitude and complexity of the socio-economic context in the food contact sector requires finding additional ways to adapt. In this context, the textile sector, respectively the field of technical textiles, through the potential of the functionalities, can make a special contribution to achieving a level of coherence between the field of functionalized materials destined for food packaging - environment - consumer health - free movement of products - efficient functioning of the internal market.

Technical textiles, a modern concept in the textile field, can be defined generically: industrial textiles/ functional textiles/hi-tech textiles/textiles of the future, and are considered as change factors for all economic, social and infrastructure fields and are characterized by:

- Alternative materials: lightweight, flexible, soft (multi/inter) functional, durable.

- A wide range of raw materials: processes, products and applications.

- New technologies: flexible, continuous, versatile.

- Reliable, multifunctional, cost-effective, functional components, parts of larger systems and technological solutions oriented towards the user.

- Positive trend to increase the consumption of unconventional textile structures. 
The global technical textiles market is expected to grow from $\$ 176.83$ billion in 2018 to $\$ 220.37$ billion by 2022 with a compound annual growth rate (CAGR) of $5.89 \%$ [9].

Among the factors that determine this growth, we can mention:

- New areas of application;

- Modifying consumer requirements;

- The multifunctional character of the technical textile properties;

- New government regulations;

- Climate change and global warming.

The group of technical textiles "PACKTECH", the important branch of the group of technical textiles, includes all packaging materials for industrial, agricultural, consumer goods and other products and can be defined by the formula [10].

$$
\text { Packaging }=(\text { Functions } / \text { Costs }) * \text { Service }
$$

The food packaging market is projected to reach a value of $\$ 305,955.1$ Million by 2019 and Asia-Pacific market is projected to grow at the highest CAGR during forecasted period (figure 3).

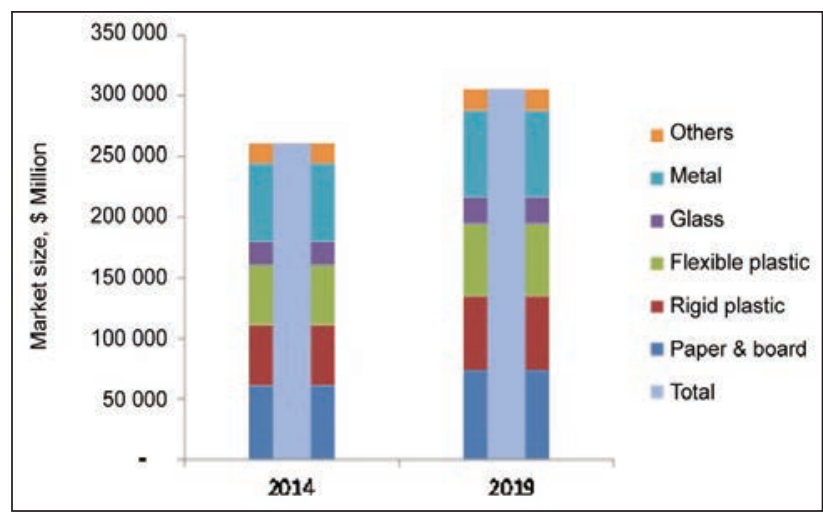

Fig. 3. Food Packaging Market Size, by Material, 2014 vs. 2019 (\$Million)/others (Wood and textile) [11]

The textile materials for packaging consumer products mainly include [12]:

- Flexible Intermediate Bulk Containers big bags (FIBC).

- Laundry bags and other bulk packaging products.

- Sacks for storage, etc.

- Twine and string for tying packages, etc. (excludes agricultural applications).

- Non-paper tea bags and coffee filters.

- Food soaker pads.

- Net packaging for storing, packing, transporting, retailing foodstuffs, toys.

- Soft luggage.

Products included in this category can be made from fabrics or unconventional textiles - non-wovens of natural fibers (cotton, organic cotton, jute, hemp, wool) or chemical fibers/yarns (polypropylene, HDPE polyethylene).

Woven sacks (except FIBC) represent about $50 \%$ of the consumption of technical textiles within Packtech, followed by bags with a share of about $30 \%$ [10].
The progression of packing demand is influenced by a wide range of factors, from year to year. While the economy plays a central role in influencing the market, there are a number of other factors that can be seen as having a direct impact or an indirect influence on the demand for packaging. These include:

- aging of the population;

- the people tendency to organize in small households;

- increasing demand for convenience;

- awareness of the importance of health among consumers:

- the modification of the lifestyle, among the consumers, increasingly poor;

- the requirements for shelving differentiation;

- environmental care;

- development of new materials;

- smaller size of food packaging;

- adopting new regulatory requirements regarding the recycling of packaging.

The growing need for reusable packaging and containers opens up new opportunities for textile products in this market.

Among the main factors underlying the choice of the optimum packaging can be mentioned [13]:

- the characteristics of the product being packaged;

- the transport and handling conditions, with the influences and the requests that intervene;

- the characteristics and aptitudes of the packaging materials;

- method of packing;

- expenses incurred in the production and transport of packaging.

All materials that come into contact with food fall within the scope of two European legislative acts, which "ensure the efficient functioning of the internal market of materials and objects intended to come in direct or indirect contact with food and provide the basis for ensuring a high level of protection of human health and consumer interests".

Regulation (EC) no. 1935/2004 on materials and objects intended to come into contact with foodstuffs, also known as the Framework or FCM Regulation establishes general requirements for all FCMs.

Regarding textile packaging, the regulation provides (table 3) [15].

Regulation (EC) no. 2023/2006 on good manufacturing practices for materials and objects intended to come into contact with food, also known as GMP Regulation.

The architecture of the respective legislation also includes:

- specific directives/regulations regulating some of the special materials and articles listed in the framework regulation.

- directives/regulations regarding the individual substances or groups of substances used in the manufacture of FCM.

The functions that must be fulfilled by the packaging, including the textile ones, are defined taking into account the preservation - protection, handling - 


\begin{tabular}{|c|c|}
\hline \multicolumn{2}{|r|}{ FCM TYPE VS GENERAL MEASURES } \\
\hline FCM type & General measures \\
\hline Textiles & $\begin{array}{l}\text { Regulation (EC) no. 1935/2004 } \\
\text { Harmonized EU legal framework that sets out the general principles on the safety and inertia of all } \\
\text { FCMs. } \\
\text { Principles: } \\
\text { - not to release their constituents in food products to an extent harmful to human health; } \\
\text { - not to produce an unacceptable change in the composition, taste and smell of food; } \\
\text { Requirements: } \\
\text { - special rules for active and intelligent materials (they are not inert by their design); } \\
\text { - competencies to adopt additional EU measures for some specific materials (for example, for plastics); } \\
\text { - the procedure for conducting safety assessments for substances used in the manufacture of FCMs, } \\
\text { which involves the European Food Safety Authority; } \\
\text { - labelling rules, including an indication of use (e.g. a coffee machine, a bottle of wine or a tablespoon) } \\
\text { or by reproducing the symbol; } \\
\text { - compliance documentation and traceability. }\end{array}$ \\
\hline
\end{tabular}

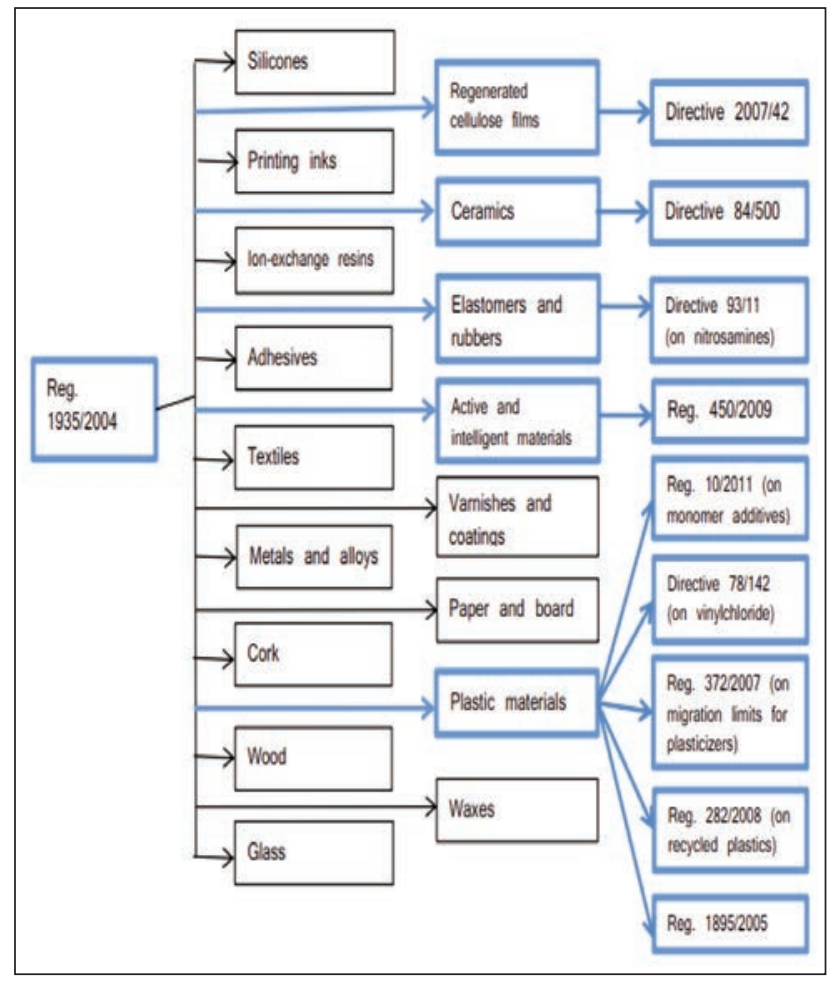

Fig. 4. Regulation (EC) No 1935/2004 [14]

storage of the products as well as the information of the consumers (table 4) [16-18].

In April 2019 the groups [19] from the civil society published 5 principles that the EU must take into account in the field evaluation activity, respectively:

- a high degree of protection of human health;

- special attention to the presence of chemicals in materials and articles that come into contact with food;

- an effective implementation;

- application of the concept of circular economy;

- transparency and participation.

Currently, Romania is in an important moment when it must adopt a strategic position towards the challenges and opportunities of wide scope. In this respect, Romania must maximize the favourable global and European trends, as well as its own competitive advantages.

In this context, the textile sector, respectively the field of technical textiles, through the potential of functionalities, can make a special contribution to achieving a level of coherence between the field of functionalized materials intended for food packaging - environment - consumer health - free movement of products efficient functioning of the internal market.

\section{CONCLUSIONS}

- The packaging must be studied both as a product - packaging system and as a distinct part which is often the determining factor in the decision to purchase the product. Product analysis in relation to the environment/man/equipment is very useful for new products.

- When choosing the materials that underlie the production of packaging in general, and textiles in particular, a basic criterion is to ensure the requirements of the product protection function, respectively:

- Protection against physical factors, of which it is worth mentioning the light protection that can cause discoloration and degradation of the goods (photochemical reactions, colour alteration, loss of vitamins.

- Chemical protection refers to the protection of products against certain aggressive chemicals. For this purpose the packaging plays the role of barrier: in the transfer of gas from the outside to the inside of the packaging; against volatile substances, which may cause alteration of the organoleptic properties of the products; at the transfer of gases from the inside to the outside, in order to avoid losing the specific flavours of the product; dehydration of the product; the loss of the gaseous mixture that was introduced inside the package in order to preserve the product.

- Protection against biological factors: avoiding contamination of products; limiting the gas exchanges susceptible to the appearance and 


\begin{tabular}{|c|c|}
\hline \multicolumn{2}{|r|}{ THE FUNCTIONS OF PACKAGES } \\
\hline $\begin{array}{l}\text { The functions } \\
\text { of packages }\end{array}$ & Protection \\
\hline $\begin{array}{c}\text { Product } \\
\text { preservation } \\
\text { and protection } \\
\text { function }\end{array}$ & $\begin{array}{l}\text { The protection function is summarized in three particular aspects as follows: } \\
\text { - protecting the product from the action of internal and external factors; } \\
\text { - protecting the environment against the toxic nature of some products; } \\
\text { - intact preservation of the quality of the goods at the direct product-packaging contact (avoiding the } \\
\text { negative influence by the packaging of the product quality); } \\
\text { - physical factors: mechanical actions, light, temperature, pressure; } \\
\text { - chemical and physico-chemical factors: air, water, oxygen vapor, sulfur dioxide, carbon dioxide; } \\
\text { - biological factors: (microorganisms, insects etc.). } \\
\text { When choosing the material from which the packaging is made, the following is taken into account: } \\
\text { - the nature of the product to be packed (aggregation state, physico-chemical and biological prop- } \\
\text { erties); } \\
\text { - own chemistry (choosing packaging materials that are chemically inert to the product and the envi- } \\
\text { ronment). }\end{array}$ \\
\hline $\begin{array}{l}\text { The handling, } \\
\text { transport and } \\
\text { storage/ } \\
\text { rationalization } \\
\text { function }\end{array}$ & $\begin{array}{l}\text { Rationalization and promotion of typical, modular packaging to facilitate the operations of handling, } \\
\text { transport and storage, the use of depreciation and fixing materials, are aspects that demonstrate the } \\
\text { rationalization function: } \\
\text { - handling the product by shape, volume; } \\
\text { - adapting the packaging to the norms and the specific means of transport; } \\
\text { - taking over the pressure during the stacking operation. }\end{array}$ \\
\hline $\begin{array}{l}\text { The function of } \\
\text { information and } \\
\text { sales promotion }\end{array}$ & $\begin{array}{l}\text { The packaging has an important communication function when presenting and selling the products, } \\
\text { since most of the products sold packaged it is obvious that the packaging also has a dual role of } \\
\text { promoting the sale and carrying the information to the consumer. The packaging represents an inter- } \\
\text { face with which the consumer comes in direct contact, which is why the packaging has to be thought } \\
\text { out to attract the buyers and to trigger the act of purchase, the packaging has also been called the } \\
\text { 'silent seller' of the product. The elements that contribute to the fulfilment of the function of promoting } \\
\text { the sales and informing the consumer that they have the packages are: the way of manufacture, the } \\
\text { system of marking and labelling, but especially the aesthetics of the packaging, that is to say the } \\
\text { aspects regarding the form, the colour and the harmony, the graphics of the packaging. These } \\
\text { elements need to be harmonized to attract the attention of the buyer. The packaging must ensure a } \\
\text { positive visual impact. Thus, in order to have the chance to be bought by the consumer, a product } \\
\text { must first be seen and be able to be identified from all the products on the shelf: } \\
\text { - the product-consumer interface; } \\
\text { - identifying and presenting the product, informing the buyers, creating a positive attitude towards } \\
\text { the product, changes in the mind-set and habits of the buyer, communicating with the customer; } \\
\text { - identifying the product and its brand, presenting the characteristics and conditions of use; } \\
\text { creating a favourable image of the product. }\end{array}$ \\
\hline
\end{tabular}

development of pathogenic germs; ensuring sealing of microbial germs, sterilization conditions for products that require this treatment.

- The present packages of textile materials have a limited use, due to some disadvantages, respectively:

- Constitutes a favourable environment for the development of microorganisms.

- They are attacked by rodents, insects and do not resist fire.

- Products in this category can be made from unconventional fabrics or textiles - non-woven from natural fibers (cotton, organic cotton, jute, hemp, wool) chemical fibers/yarns (polypropylene, HDPE polyethylene, etc.).

- The objectives of the testing activity of the textile structures destined to the packaging of the products are: evaluation of the basic and functional characteristics of the product and the prediction of the performances during the use. The information obtained can be used in the research-development activity, the selection of the raw material base, the development of processes, control activities, quality control, production testing, product failure analysis, comparing tests, compliance with legal regulations.

- The new textile materials, which bring functionalities and superior levels of performance in the field of packaging, are based on: innovative technologies, natural organic fibers, recyclable, biodegradable, unconventional mixtures of natural fibers, structural eco-design methods, up-cycling techniques, active elements (traceability devices, indicators, sensors).

- Smart (active and intelligent) textile materials for food contact can and should change the quality of life, and just as all materials must be a source of sustainability, be recyclable, ensure safety and quality, take into account the consumer experience, to provide as much information as possible, to contribute to the reduction of food waste, to be connected with the respective brands.

\section{ACKNOLEDGEMENT}

This work was supported by a grant of the Romanian Research and Innovation Ministry, through Sectorial Plan, contract no. 3PS/2019. 


\section{REFERENCES}

[1] ECOSIGN, Food Packaging, Available at: http://www.ecosign-project.eu/food-packaging/ [Accessed November 2019]

[2] Bazgă, B., Chelmu, S.S., Securitatea alimentară: Potențialul agricol, componentă a securității naționale a României, 2013, Available at: https://intelligence.sri.ro/securitatea-alimentara-potentialul-agricol-componentasecuritatii-nationale-romaniei/ [Accessed November 2019]

[3] Purcarea, C., Popa, A., et al., Rolul ştiinţelor şi tehnologiilor în siguranta alimentara în corelaţie cu alimentaţia sănătoasă şi rolul său în prevenirea unor boli metabolice, ISBN 978-3-9503145-1-9, Vienna, 2012

[4] Pro Alimente-dincolo de ambalaj, Factori care pot afecta inlocuitatea produselor alimentare, 2016, Available at: http://proalimente.com/inocuitatea-produselor-alimentare/ [Accessed November 2019]

[5] Hojda, A., Siguranta si securitatea alimentara, Available at: https://www.academia.edu/10154491/ESEU_ siguranta_si_securitatea_alimentara [Accessed November 2019]

[6] QReferat, Nutrienti alimentari, Available at: http://www.qreferat.com/referate/alimentatie/Nutrienti-alimentari 248.php [Accessed November 2019]

[7] Roberge, D., How To Develop Your Ideal Packaging Strategy, 2018, Available at: https://www.industrial packaging.com/blog/how-to-develop-your-ideal-packaging-strategy [Accessed November 2019]

[8] Learn Marketing, 2019, Available at: https://www.learnmarketing.net/packagingstrategies.htm [Accessed November 2019]

[9] Technical Textile Market, Technical Textile Market by Material (Natural Fiber, Synthetic Polymer, Metal, Mineral, Regenerated Fiber), by Process (Woven, Knitted, Non-woven), by Application (Mobiltech, Indutech, Protech, Buildtech, Packtech), and Region - Global Forecast to 2022, 2018, Available at: https://www.marketsand markets.com/Market-Reports/technical-textile-market-1074.html [Accessed November 2019]

[10] Textile Learner, Advantages and Uses of Textile Packaging Material, Available at: https://textilelearner.blogspot. com/2013/01/packtech-textile-packaging-material.html, [Accessed November 2019]

[11] MarketsandMarkets, Food Packaging Market by Material (Paper \& Board, Plastic, Glass, Metal), Type (Rigid, SemiRigid, Flexible), Application (Dairy, Bakery, Confectionery, Convenience Foods, Fruits, Vegetables, Meat, Sauces, Dressings) - Global Trends \& Forecast to 2019, 2014, Available at: https://www.marketsandmarkets.com/MarketReports/food-packaging-market-70874880.html, [Accessed November 2019]

[12] Dirgar, E., Oral, O., Packing Textiles and Their Application Areas, XIII ${ }^{\text {th }}$ International Izmir Textile and Apparel Symposium, April 2-5, 2014

[13] Definirea şi clasificarea ambalajelor, 2017, Available at: https://conspecte.com/Merceologia-marfuriloralimentare/definirea-si-clasificarea-ambalajelor.html [Accessed November 2019]

[14] ANEC Position Paper on the implementation of the FCM legislation, 2016, Available at: http://www.anec.eu/ images/Publications/position-papers/Chemicals/ANEC-PT-2016-CEG-021.pdf [Accessed November 2019]

[15] Food Safety Authority of Ireland, Food Contact Materials, 2014, 1, Available at: file:///C:/Users/Crina/Downloads/ Food\%20Contact\%20Materials\%20FINAL\%20(2).pdf [Accessed November 2019]

[16] Cojoaca, M., Ambalarea și etichetarea mărfurilor, 2013, Available at: https://www.academia.edu/32377149/FdSM_ Tema_10._Ambalarea_\%C8\%99i_etichetarea_m\%C4\%83rfurilor [Accessed November 2019]

[17] Packaging, Available at: http://www.scritub.com/tehnica-mecanica/Ambalarea3363176.php [Accessed November 2019]

[18] The importance of food packaging, Available on: http://www.rasfoiesc.com/business/economie/merceologie/ IMPORTANTA-AMBALAJULUI-ALIMENT91.php [Accessed November 2019]

[19] HEAL- Health and Environment Alliance, Food contact materials and chemical contamination, May 2019, Available at: https://www.env-health.org/wp-content/uploads/2019/06/Food-Contact-Materials-Briefing-Health-and-environmentAlliance-HEAL-PRINT_final-1.pdf [Accessed November 2019]

\section{Authors:}

\section{EFTALEA CĂRPUȘ, ANGELA DOROGAN, CRISTINA STROE}

National R\&D Institute for Textiles and Leather - INCDTP, Lucretiu Patrascanu Street, no. 16, 030508, Bucharest, Romania

\section{Corresponding author:}

\section{EFTALEA CĂRPUȘ}

e-mail: eftalea.carpus@incdtp.ro 